\title{
Dust storm hazards
}

\author{
Nick Middleton ${ }^{1 *}$ \\ ${ }^{1}$ St Anne's College, University of Oxford, Oxford OX2 6HS, UK
}

\begin{abstract}
Dust storms originate in many of the world's drylands and frequently present hazards to human society, both within the drylands themselves but also outside drylands due to long-range transport of aeolian sediments. Desert dust hazards can occur where dust is entrained, during the transport phase, and on deposition. This paper draws on studies in physical geography, medical geology and geomorphology to discuss case studies of accelerated soil erosion, the health effects of air pollution caused by desert aerosols, injuries related to transport accidents caused by poor visibility during desert dust events, the spread of disease, and problems with water supplies and at solar power plants caused by dust deposition.
\end{abstract}

\section{INTRODUCTION}

Desert dust has numerous wide-ranging impacts on the Earth system and on human society both within the world's deserts and semi-deserts, where most dust storms originate, and beyond the drylands due to longrange transport $[1,2]$. Desert dust hazards threaten livelihoods, environment and economy, and are likely to undermine the implementation of several Sustainable Development Goal (SDG) targets established by the United Nations (UN), particularly those related to human health, productivity, agriculture and infrastructure (transport). Hence, the UN General Assembly adopted resolutions entitled "Combatting sand and dust storms" in 2015 (A/RES/70/195), 2016 (A/RES/71/219) and 2017 (A/RES/72/225). Other recent resolutions concerning sand and dust storms have been adopted by the UN Economic and Social Commission for Asia and the Pacific (resolution 72/7) and the UN Environment Assembly (resolution 2/21), both in 2016 .

These resolutions acknowledge that sand and dust storms represent a severe impediment to the sustainable development of affected developing countries and the well-being of their peoples and urge individual countries to address these challenges through relevant policy measures. Progress towards meeting these challenges by the World Meteorological Organization began in 2007 when it initiated its Sand and Dust Storm Warning Advisory and Assessment System (SDS-WAS), but research into desert dust hazards is relatively sparse, despite a policy framework for sand and dust storms being developed by the UN Convention to Combat Desertification (UNCCD) in 2017. This paper reviews the ways in which desert dust is related to hazardous conditions experienced by human populations both within drylands and beyond their margins.

\section{HAZARDS ASSOCIATED WITH DUST STORMS}

Dust storms create hazards for human society in numerous ways [3] and these hazards are classified in Table 1 according to the three processes of the wind erosion system: on entrainment of fine particles, during their transport, and on their deposition.

Table 1. Hazards to human populations caused by wind erosion and dust storms. Modified from [3].

\begin{tabular}{|c|c|c|}
\hline Entrainment & Transport & Deposition \\
\hline Soil loss & $\begin{array}{l}\text { Sand-blasting of } \\
\text { crops }\end{array}$ & $\begin{array}{l}\text { Salt deposition } \\
\text { and groundwater } \\
\text { salinization }\end{array}$ \\
\hline $\begin{array}{l}\text { Nutrient, seed } \\
\text { and fertilizer } \\
\text { loss }\end{array}$ & $\begin{array}{l}\text { Radio } \\
\text { communication } \\
\text { problems } \\
\end{array}$ & $\begin{array}{l}\text { Reduction of } \\
\text { reservoir storage } \\
\text { capacity }\end{array}$ \\
\hline $\begin{array}{l}\text { Crop root } \\
\text { exposure }\end{array}$ & $\begin{array}{l}\text { Microwave } \\
\text { attenuation }\end{array}$ & $\begin{array}{l}\text { Drinking-water } \\
\text { contamination }\end{array}$ \\
\hline \multirow[t]{6}{*}{$\begin{array}{l}\text { Undermining } \\
\text { structures }\end{array}$} & $\begin{array}{l}\text { Transport } \\
\text { disruption }\end{array}$ & $\begin{array}{l}\text { Ice melt due to } \\
\text { dust radiative } \\
\text { forcing }\end{array}$ \\
\hline & $\begin{array}{l}\text { Local weather and } \\
\text { climatic effects }\end{array}$ & $\begin{array}{l}\text { Crop damage } \\
\text { and growth } \\
\text { problems }\end{array}$ \\
\hline & Air pollution & $\begin{array}{l}\text { Burial of } \\
\text { structures }\end{array}$ \\
\hline & $\begin{array}{l}\text { Respiratory } \\
\text { problems and eye } \\
\text { infections }\end{array}$ & $\begin{array}{l}\text { Machinery } \\
\text { problems }\end{array}$ \\
\hline & $\begin{array}{l}\text { Disease } \\
\text { transmission } \\
\text { (human) }\end{array}$ & $\begin{array}{l}\text { Reduction of } \\
\text { solar power } \\
\text { potential }\end{array}$ \\
\hline & $\begin{array}{l}\text { Disease } \\
\text { transmission } \\
\text { (plants \& animals) }\end{array}$ & $\begin{array}{l}\text { Power supply } \\
\text { disruption } \\
\text { (electrical } \\
\text { insulator failure) }\end{array}$ \\
\hline
\end{tabular}

\footnotetext{
* Corresponding author: nicholas.middleton@st-annes.ox.ac.uk
} 
Hazards range from local sand-blasting of field crops to human health issues associated with dust haze. Indeed, desert dust presents a unique form of natural hazard in that the source and impact regions can be separated by considerable distances and these regions are frequently separated by international borders, so that dust hazards are often transboundary issues. These dust storm hazards are experienced by societies all over the world, within and beyond drylands, but are particularly severe in Africa and Asia. Where possible, the emphasis in this paper is on Asian examples.

\subsection{Entrainment phase}

Dust storms create hazards in the entrainment phase largely when and where particulate material is mobilized from agricultural fields, in which case a dust storm represents a frequently severe form of accelerated soil erosion [4]. Soil particles, nutrients, fertilizers and seeds are lost and the eroded particles may also cause serious damage to crops by abrasion, an issue that is particularly critical for young shoots. Soil structure and soil moisture storage are adversely affected, fertility is commonly reduced, and overall the loss of topsoil typically results in a detrimental effect on crop yields.

One of the best-known examples of large-scale wind erosion and dust storm activity anywhere in the world occurred on the Great Plains of the USA during the 1930s after pioneering farmers ploughed up the plains for cultivation. The drivers of this ecological disaster were both physical and social, a combination of drought and socio-economic factors [5], exacerbated by the severe economic problems affecting North America at the time, which made it very difficult for farmers adequately to deal with this environmental catastrophe. The degree of aridity over the Great Plains during the 1930s was also unusual and may have been prolonged by feedback effects caused by reduced vegetation cover and large-scale emissions of soil dust, both consequences of crop failure [6].

Similar widespread wind erosion of soils resulted from analogous expansion of cultivation into grasslands in the Argentine Pampas during the 1930s and 1940s and after the 1950s Virgin Lands Scheme in Western Siberia and northern Kazakhstan, then part of the former Soviet Union. Wind erosion remains a serious issue today in many dryland and drought-prone agricultural areas of the world.

\subsection{Transport phase}

Dust suspended in the atmosphere has implications for human health due to its physical, chemical and biological properties [7]. Inhalation of dust can cause respiratory illnesses such as silicosis and act as a trigger for many others, including asthma, bronchitis, emphysema and chronic obstructive pulmonary disease. Particle size is the main determinant of where dust, once inhaled, comes to rest in the respiratory tract. Medical authorities commonly highlight a distinction between particles $<10 \mu \mathrm{m}\left(\mathrm{PM}_{10}\right)$ in diameter, which can penetrate into the lungs, and those with diameter $<2.5 \mu \mathrm{m}\left(\mathrm{PM}_{2.5}\right)$ which penetrate into deep lung tissue. International and national health authorities have issued air quality guidelines for acceptable atmospheric concentrations at the chronic level (annual mean) and acute level (24-hr mean), but these levels are frequently exceeded in, and downwind of, desert areas. Desert dust is by no means the only source of atmospheric particulates in such areas, of course. Other sources common to urban areas in particular include motor vehicles and a variety of industries, but Table 2 shows a selection of major desert settlements where annual mean values of $\mathrm{PM}_{10}$ are an order of magnitude higher than the WHO guideline, and annual mean $\mathrm{PM}_{2.5}$ is commonly also far beyond the recommended air quality guidelines.

Table 2. Mean annual atmospheric concentrations of particulate matter for a selection of major settlements in Asia and the Middle East.

\begin{tabular}{|l|r|r|}
\hline Location & $\begin{array}{l}\text { PM10 } \\
\text { annual } \\
\text { mean } \\
\left(\boldsymbol{\mu g} / \mathbf{m}^{3}\right)\end{array}$ & $\begin{array}{l}\text { PM2.5 } \\
\text { annual } \\
\text { mean } \\
\left(\boldsymbol{\mu g} / \mathbf{m}^{\mathbf{3}}\right)\end{array}$ \\
\hline Peshawar, Pakistan & 540 & 111 \\
\hline Al Jubail, Saudi Arabia & 359 & 152 \\
\hline Mazar-e Sharif, Afghanistan & 334 & 68 \\
\hline Hamad Town, Bahrain & 318 & 66 \\
\hline Ahvaz, Iran & 231 & 95 \\
\hline Al-Shuwaikh, Kuwait & 212 & 88 \\
\hline Baghdad, Iraq & 208 & 88 \\
\hline Jaipur, India & 187 & 100 \\
\hline Urumqi, China & 146 & 64 \\
\hline Al Gharbia, UAE & 146 & 62 \\
\hline Al-Zarqa, Jordan & 128 & 54 \\
\hline $\begin{array}{l}\text { World Health Organization air } \\
\text { quality guidelines }\end{array}$ & 20 & 10 \\
\hline \multicolumn{1}{|c|}{ Data from WH Ambient Air Pon } & & \\
\hline
\end{tabular}

Data from WHO Ambient Air Pollution Database accessed September 2018.

Individual storms are associated with much higher concentrations of atmospheric dust, and the levels measured frequently exceed recommended health levels for the 24-hour mean as shown in Table 3.

Table 3. Maximum $\mathrm{PM}_{10}$ levels observed in dust storms in Asia and the Middle East.

\begin{tabular}{|l|r|r|r|}
\hline Location & \multicolumn{1}{|l|}{ Date } & \multicolumn{1}{|l|}{$\begin{array}{l}\mathbf{P M}_{\mathbf{1 0}} \\
\left(\boldsymbol{\mu g} / \mathbf{m}^{\mathbf{3}}\right)\end{array}$} & \multicolumn{1}{|c|}{ Source } \\
\hline Sanandaj, Iran & 5 Jul 2009 & 5619 & {$[8]$} \\
\hline Ahvaz, Iran & Jun 2010 & 5338 & {$[9]$} \\
\hline Beer-Sheva, Israel & 29 Feb 2012 & 5197 & {$[10]$} \\
\hline Jahra city, Kuwait & 27 Mar 2003 & 3171 & {$[11]$} \\
\hline Zabol, Iran & Dec 2010 & 3094 & {$[12]$} \\
\hline Bikaner, India & 25-26 May 2000 & 2907 & {$[13]$} \\
\hline Urumqi, China & May 2004 & 2635 & {$[14]$} \\
\hline Lanzhou, China & 29 Feb 2008 & 2078 & {$[15]$} \\
\hline Abu Dhabi, UAE & 20 Mar 2012 & 1653 & {$[16]$} \\
\hline $\begin{array}{l}\text { Zamyn-Uud, } \\
\text { Mongolia }\end{array}$ & 26 May 2008 & 1228 & {$[17]$} \\
\hline $\begin{array}{l}\text { WHO air quality } \\
\text { guideline (24- } \\
\text { hour mean) }\end{array}$ & - & 50 & \\
\hline
\end{tabular}

The very large quantities of desert dust moved during some long-distance transport events also means that such 
elevated concentrations can be experienced at considerable distances from dust source areas [3], as indicated in Figure 1. Many epidemiological studies show possible associations of dust exposure with increases in mortality and hospital visits and admissions due to respiratory and cardiovascular diseases, although causative links are difficult to establish and the methodologies used in these types of study are varied. The World Health Organization (WHO) is engaged in a global assessment of such work.

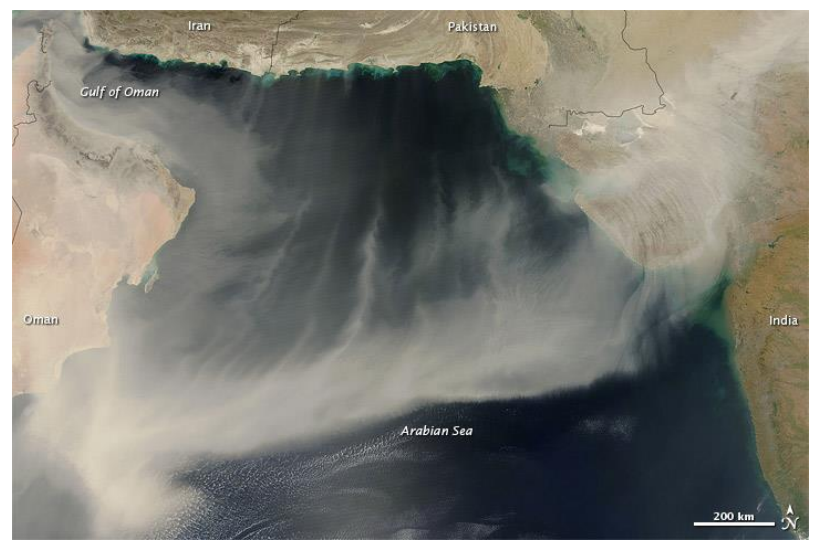

Fig. 1. A huge cloud of desert dust billowing out from the Arabian Peninsula over the Arabian Sea and southwest Asia in March 2012 (image: NASA).

Microbiological studies have established that desert dust can contain a wide variety of microorganisms including fungi, bacteria and viruses - capable of causing disease in a range of organisms, such as trees, crop plants and animals as well as people [18]. In human populations, a number of diseases are linked to desert aerosols, including influenza A virus, bacterial pneumonia, Kawasaki disease, coccidioidomycosis (also known as Valley Fever) and meningococcal meningitis. In subSaharan Africa, the highest incidence of meningococcal meningitis occurs in the so-called Meningitis Belt and periodic epidemics of the disease during the dry season are closely related in their timing to the dust-laden Harmattan wind, although the precise role of mineral dust is yet to be established [19].

Desert dust in suspension also presents problems for various modes of transport, resulting in an increase in accidents on the ground and in the air. Poor visibility is a frequent cause, often in combination with very strong winds and adverse mechanical effects caused by dust, such as damage to moving parts, windscreens and engine intakes. For these reasons roads, airports, railway lines and on occasion seaports, are frequently closed during intense dust events.

Dust storms have been implicated in a number of aircraft accidents involving fatalities as shown in Table 4. Attribution of cause in such crashes is seldom straightforward, and often involves a combination of factors, but all the accidents shown in Table 4 involved dust storms to some extent.

Loss of visibility may be very sudden when caused by the arrival of a dust wall associated with a dry thunderstorm, or Haboob, and such dust walls have been shown to lead directly to road traffic accidents in at least Australia, the USA, Iran, Kuwait, the UAE and Germany [20], although this is a relatively under-studied aspect of desert dust. In the USA, 62 deaths nationally were related to dust storms affecting road vehicles between 1980 and 2005 [21].

Table 4. Some fatal commercial aircraft crashes attributed at least in part to dust storms.

\begin{tabular}{|l|l|l|l|}
\hline Location & Date & Airline & Fatalities \\
\hline $\begin{array}{l}\text { Côte } \\
\text { d'Ivoire }\end{array}$ & 30 Jan 2000 & $\begin{array}{l}\text { Kenya } \\
\text { Airways }\end{array}$ & 179 dead \\
\hline $\begin{array}{l}\text { Tunis, } \\
\text { Tunisia }\end{array}$ & 7 May 2002 & EgyptAir & 18 dead \\
\hline $\begin{array}{l}\text { Faridabad, } \\
\text { India }\end{array}$ & 25 May 2011 & $\begin{array}{l}\text { Air Chartered } \\
\text { Services }\end{array}$ & 10 dead \\
\hline $\begin{array}{l}\text { Talodi, } \\
\text { Sudan }\end{array}$ & 19 Aug 2012 & $\begin{array}{l}\text { Sudan } \\
\text { Airways }\end{array}$ & 31 dead \\
\hline
\end{tabular}

\subsection{Deposition phase}

The rate of desert dust deposition can be considerable. In Central Asia, a long-term monitoring programme [22] at stations in Uzbekistan, Kazakhstan and Turkmenistan between 2003 and 2010 found the highest deposition rates in the Uzbek part of the Aral Sea basin, on the southern margins of the Kyzyl Kum and Aral Kum deserts (Bozaubay, Jasliq and Mynak in Table 5). Annual rates in these areas were much greater than those monitored at locations around the Kara Kum desert in Turkmenistan and at Aralsk to the north of the Aral Sea.

Table 5. Mean annual dust deposition rates recorded in Central Asia.

\begin{tabular}{|l|r|}
\hline Location & $\begin{array}{r}\text { Deposition rate } \\
\left(\mathbf{g} / \mathbf{m}^{\mathbf{2}} \mathbf{)}\right.\end{array}$ \\
\hline Bozaubay, Uzbekistan & 8365 \\
\hline Jasliq, Uzbekistan & 2466 \\
\hline Mynak, Uzbekistan & 537 \\
\hline Repetek, Turkmenistan & 214 \\
\hline Bokurdak, Turkmenistan & 205 \\
\hline Darvaza, Turkmenistan & 171 \\
\hline Aralsk, Kazakhstan & 162 \\
\hline Kunya-Urgench, Turkmenistan & 155 \\
\hline
\end{tabular}

Data from [22]

The deposition of dust has implications for residents both within and beyond desert areas, although some of the issues are difficult to separate from those associated with dust in the transport phase. Road and rail routes that run through desert areas are typically hindered by sand and dust storms that result in the deposition of sediments (both sand- and dust-sized material) as well as the various problems associated with dust in suspension as outlined in section 2.2. In the nineteenth century, during the early years of the Trans-Caspian railway, each train carried a special team of workers to clear the tracks of drifting sand, a problem that led directly to the creation in 1912 of the 
Desert Research Station at Repetek in Turkmenistan [23], now part of the Repetek International Biosphere Reserve. Research at Repetek and elsewhere has led to the development of a variety of techniques to stabilise sand dunes ranging from shelterbelts, barriers or fences to surface treatments with chemicals. Specially designed sand removal machines that move along the rails are now used in some countries instead of men with shovels, but the deposition of material is still a serious issue facing many desert rail routes. A recent review [24] outlines the continuing problems encountered along in-service railway lines crossing deserts in several parts of Asia and the Middle East - particularly in western China, and Rajasthan in India - and new routes in Saudi Arabia and the United Arab Emirates.

Dust deposition in households and commercial buildings requires major efforts and economic costs for interior cleaning and domestic landscaping clean-ups. Such deposits also reduce reservoir storage capacity, and clog streams and drainage channels. Water quality may also be contaminated [25] with microorganisms and/or with anthropogenic materials picked up and transported in dust storms. These include pesticides, herbicides, heavy metals, dioxins, and radioactive isotopes. In Asia, significant historical sources of dust contaminated by radioactive material were associated with the nuclear weapons tests conducted by the former Soviet Union at Semipalatinsk (now in Kazakhstan) and by China at Lop Nor [26].

High salinity is typical of dust blown from the ephemeral salt lakes (commonly known as playas, pans, salars or sebkhas) that are frequently found in many drylands, and contamination can occur when such saline dusts are deposited in surrounding areas (Figure 2). Many of these salt lakes become sources of wind-blown dust when they dry out under natural conditions, seasonally or during drought periods. Others have become more permanent dust sources because their water levels have declined due to human mismanagement. A classic example of the latter situation is the desiccated former lakebed of the Aral Sea. Soil salinization due to dust deposition is a particular issue in the zone surrounding the Aral, endangering the productivity of nearby rangeland and agricultural areas. Prevailing winds from the north and north-east mean the most serious impacts occur on the Usturt Plateau to the west of the Aral Sea and the Amudarya delta to the south [27].

The deposition of dust in mountainous regions also has important implications for water supplies used for agricultural and urban purposes in surrounding lowlands. Dust deposition on snow and ice reduces the surface albedo and accelerates melting, hence affecting the magnitude and timing of meltwater and runoff availability [28]. Climate modelling simulations also indicate that aerosols such as desert dust, frequently mixed with anthropogenic pollution, can enhance climate warming when deposited on snow and ice. In the Himalaya-Tibetan Plateau region, sometimes referred to as the Water Tower of Asia, climate models have also indicated that the summer monsoon circulation may be perturbed by the effects of mineral dust deposition.

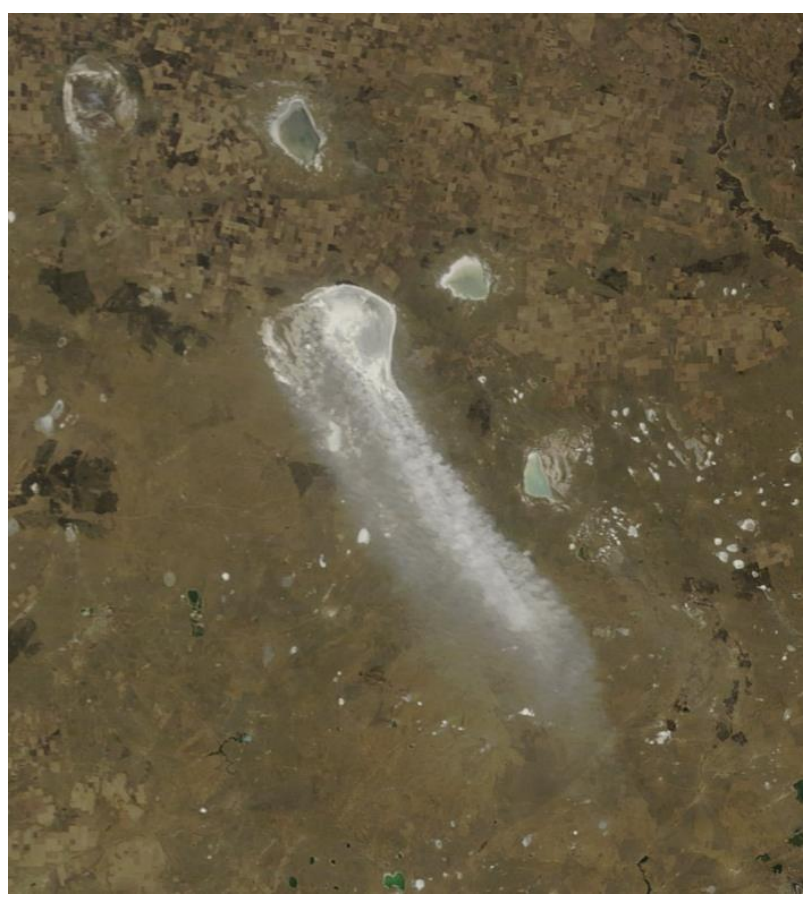

Fig. 2. A plume of saline dust blown from Lake Siletiteniz in northern Kazakhstan (image: NASA).

Another utility that can be seriously affected by desert dust deposits is the power sector. The deposition of sand and dust can have serious repercussions for the operation of solar power plants, adversely affecting the two main technologies used: photovoltaic (PV) and concentrating solar-thermal power (CSP) systems [29]. Power can be reduced in PV systems typically by $15 \%$ to $30 \%$ in moderate dust conditions but can reach $100 \%$ if cementation by water-soluble salts occurs due to the combination of dew, very light rain, or humidity with dust. CSP systems are even more sensitive to dust accumulation and require greater maintenance to mitigate deposition. The reliability of power distribution grids in desert areas can also be adversely affected by dust [30]. Small desert particles frequently carry an electrical charge that interferes with porcelain insulators on high-voltage transmission lines, reducing effective distribution and potentially resulting in flashover outages.

\section{ECONOMIC ASSESSMENT OF DUST STORM HAZARDS}

Particular dust events of course result in multiple impacts. In May 2018, more than 100 people were reported killed in the very strong winds and lightning strikes associated with a powerful dust storm in northwestern India. Many of the deaths occurred after walls and roofs of houses collapsed in the middle of the night due to the fierce winds, or as trees fell onto the buildings. Thousands of electricity poles were blown over resulting in widespread power cuts and water shortages. Later in the same month, a series of powerful dust storms swept over a much wider area of central and southwest Asia, impacting parts of Uzbekistan and Turkmenistan, eastern regions of Iran, southwestern Afghanistan, northwestern Pakistan and 
northwestern states of India. An estimated thousand people were killed and millions more affected.

Given the importance of desert dust as a hazard to human societies, it is surprising to note that dust storms seldom feature in the disasters literature and that there have been relatively few attempts to assess their impacts in economic terms [20]. Dust storms create damage in both the source location (on-site) and impact region (offsite). The economic impact in either location will depend on many factors, such as the level and types of economic activity, the activities undertaken in the source region that may contribute to dust storm events (e.g. agriculture, water management, mining), the relative wealth of the population in each location and other drivers of vulnerability. Further factors that should be considered include damage to environmental or ecosystem services on-site and off-site, and human aspects, such as health and income distribution in the source and/or impact region. Two types of costs are associated with natural disasters direct and indirect - and costs can be assessed both in the short- and long-term [31].

A number of approaches and methods are used to determine these various factors, and the examples cited below use different methodologies, so are not strictly comparable. Apart from the relative dearth of case studies, this lack of consistent data collection methods and analysis is a central issue with respect to measuring the economic impact of dust storms.

Most economic analyses of dust hazards are regional. For example, the total on-site and off-site costs associated with a single large storm that affected the Australian state of New South Wales in 2009 were estimated at Aus\$299 million (US\$219m), most of which was accounted for by household cleaning and disruption to commercial activities (retail and service industries), air transport and construction [32].

An assessment of the total cost of atmospheric soil dust to the city of Beijing in China in the year 2000 identified a considerable decrease in output from urban agriculture, manufacturing, construction, transportation, trade and catering services as the main sectors affected. The total cost of these direct impacts came to US\$265 million [33].

The economic impact of dust storms on three sectors (health, transport and agriculture) were assessed in Iran and Iraq for the year 2013 and in each country the cost was in the region of US\$1000 million [34]. By contrast, the costs incurred by a single branch of the transport sector - the aviation industry - were estimated for the year 2002 in South Korea by [35], who calculated that the total cost of 102 flights being cancelled that year due to desert dust in the atmosphere was US\$578,000.

\section{CONCLUSIONS}

Drylands present a range of hazards to their human occupants, of which dust storms are one of the most serious, but the significance of desert dust hazards also affects many people far beyond the dryland realm due to long-distance dust transport. There has been a considerable increase in desert dust research in recent years, but research into the hazard implications of dust is not so well advanced. As the wide range of direct and costly impacts indicates, desert dust storms warrant greater attention in this respect.

Studies of some forms of dust storm hazard, such as wind erosion in agricultural areas, are relatively mature, but others remain under-studied. The latter group includes the impacts on transport, making causal associations between exposure to desert dust particles and adverse human health effects, and the effects of dust deposition on crops. Better understanding of such subjects will also improve another facet of desert dust research that remains in its infancy: the economic impact assessment of dust events.

All aspects of desert dust hazards have received more research attention in some parts of the world than others. In Asia, the Northeast is well served in many respects, but Central Asia is notably under-studied in most regards. Improved knowledge of desert dust hazards, in all affected areas, is needed for a satisfactory response to the United Nations call for countries to address the challenges of dust storms cost-effectively through appropriate policy measures as part of their efforts towards achieving the Sustainable Development Goals.

\section{References}

1. A.S. Goudie, N.J. Middleton, Desert Dust in the Global System (Springer Verlag, Heidelberg, 2006)

2. Y. Shao, Wyrwoll, K.H., Chappell, A., Huang, J., Lin, Z., McTainsh, G.H., Yoon, S., Aeolian Res. 2, 181 (2011)

3. N.J. Middleton, Aeolian Res. 24, 53 (2017)

4. K.F. Nordstrom, S. Hotta, Geoderma 121(3), 157 (2004)

5. J.A. Lee, T.E. Gill, Aeolian Res. 19, 15 (2015)

6. B.I. Cook, R.L. Miller, R. Seager, Proc. Natl. Acad. Sci. 106, 4997 (2009)

7. A.S. Goudie, Environ. Int. 63, 101 (2014)

8. J. Amanollahi, C. Tzanis, A.M. Abdullah, M.F. Ramli, S. Pirasteh, Int. J. Environ. Sci. Technol. 10, 1245 (2013)

9. A. Shahsavani, K. Naddafi, N. Jafarzade Haghighifard, A. Mesdaghinia, M. Yunesian, R. Nabizadeh, M. Arahami, M.H. Sowlat, M. Yarahmadi, H. Saki, M. Alimohamadi, S. Nazmara, S.A. Motevalian, G. Goudarzi, J. Arid Environ. 77, 72 (2012)

10. H. Krasnov, K. Itzhak, P. Koutrakis, M.D. Friger, J. Air Waste Manag. Assoc. 64, 89e94 (2014)

11. T. M. Saeed, H. Al-Dashti, Theor. Appl. Climatol. 104, $123(2011)$

12. A. Rashki, D.G. Kaskaoutis, C.J.deW. Rautenbach, P.G. Eriksson, M. Qiang, P. Gupta, Aeolian Res. 5, 51 (2012)

13. S. Yadav, V. Rajamani, Atmos. Environ. 40, 698 (2006)

14. J. Li, G. Zhang, K. Huang, Y. Lin, C. Xu, S. Yu, Atmos. Environ. 42, 776 (2008)

15. W. Pu, X. Wang, X. Zhang, Y. Ren, J.S. Shi, J.R. Bi, B.D. Zhang, Aerosol Air Qual. Res. 15, 2212 (2015)

16. G. Basha, D.V. Phanikumar, K. Niranjan Kumar, T.B.M.J. Ouarda, P.R.Marpu, Remote Sens. Environ. 169, 404 (2015) 
17. D. Jugder, M. Shinoda, N. Sugimoto, I. Matsui, M. Nishikawa, S.U. Park, Y.S. Chun, M.S. Park, Glob. Planet. Change 78, 14 (2011)

18. C.A. Kellogg, D.W. Griffin, Trends Ecol. Evol. 21, 638 (2006)

19. C.P. García-Pando, M.C. Thomson, M.C. Stanton, P.J. Diggle, T. Hopson, R. Pandya, R.L. Miller, S. Hugonnet, Earth Perspectives 1, 14 (2014)

20. N.J. Middleton, P. Tozer, B. Tozer, Disasters (in press)

21. W.S. Ashley, A.W. Black, J. Appl. Meteorol. 47, 717 (2008)

22. M. Groll, C. Opp, I. Aslanov, Aeolian Res. 9, 49 (2013)

23. A.G. Babaev, Desert Problems And Desertification In Central Asia (Springer, Berlin, 1999, 5)

24. L. Bruno, M. Horvat, L.J. Raffaele, Wind. Eng. Ind. Aerodyn. 177, 340 (2018)

25. I. Reche, E. Ortega-Retuerta, O. Romera, E.P. Villena, R.M. Baquero, E.O. Casamayor, Limnol. Oceanogr. 54, 869 (2009)

26. M. Yamamoto, J. Tomita, A. Sakaguchi, Y. Ohtsuka, M. Hoshi, K.N. Apsalikov, J. Radioanal. Nucl. Chem. 284, 309 (2010)

27. G. Issanova, J. Abuduwaili, O. Galayeva, O. Semenov, T. Bazarbayeva, Int. J. Environ. Sci. Technol. 12, 3213 (2015)

28. T.H. Painter, S.M. Skiles, J.S. Deems, W.T. Brandt, J. Dozier, Geophys. Res. Lett. 45, 797 (2018)

29. T. Sarver, A. Al-Qaraghuli, L.L. Kazmerski, Renewable Sustainable Energy Rev. 22, 698 (2013)

30. P.J. Maliszewski, E.K. Larson, C. Perrings, Reliab. Eng. Syst. Safe. 99, 161 (2012)

31. S. Hallegatte, V. Przyluski, Policy Research Working Paper 5507, World Bank Sustainable Development Network (2010)

32. P. Tozer, J. Leys, Rangeland J. 35, 131 (2013)

33. N. Ai, K.R. Polenske, Econ. Syst. Res. 20, 187 (2008)

34. A.E. Meibodi, G. Abdoli, A. Taklif, B. Morshedi, Proc. Econ. Finance 24, 409 (2015)

35. G.G. Kang, J.M. Chu, H.S. Jeong, H.J. Han, N.M. Yoo, An Analysis of the Damage From Yellow Dust in Northeastern Asia and Regional Cooperation Strategy for Reducing Damage. (Korea Environment Institute, Seoul, 2004) 